$$
\text { オーストリア及びスカンジナビアの地すべり }
$$

\title{
Landslides in Austria and Scandinavia
}

\section{佐 々 恭 二* \\ Kyoji SASSA}

\section{Summery}

The author had a chance to visit landslides in Austria, Scandinavia, England and Czechoslovakia with the fellowship of the Japan Society for the Promotion of Science and the subsidy of the Disaster Prevention Research Association during June 1977-June 1978.

The landslides in Czechoslovakia and England were already reported in this journal. Therefore, the author will report the four types of landslides and their examples in Austria and Scandinavia as written below.

1) The landslide in Moraine; Embacher Blaike and Schesatobel

2) The landslide in Crystalline schist; The Graden Bach landslide

3) The landslide in Marl; Gschliefgraben

4) The landslide in Quick clay; The Romerike landslide and the Tuve landslide

\section{1. まえがき}

昭和52年 6 月より一年間, 日本学術振興会, 防災研究 協会の援助により，英国のインペリアル・カレッジに10 カ月学び, アルプス諸国，スカンジナビア諸国の地すべ り，砂防を約 2 力月視察する機会を得た。筆者が訪れた 地すべりの中で與味深かったのは，オーストリアの結晶 片岩の地すべり, 水河堆積物 (Moraine) の地すべり及 び泥灰岩（Marl）の地すべりとスカンジナビアのクイッ ク・クレイ (Quick clay) の地すべりである。またチェ コの地すべりや英国の地すべりにも興味あるものがある が, 前者については中村 $(\text { 浩之 })^{8)}$, 西田 ${ }^{9)}$, 湊元 ${ }^{7)}$, 寺
川6)などの報告があり，後者については酒井4)が報告し ているチョークの地すべり（参13等の報告がある）とン リフラクションの地すべり（参14, 18等の論文がある） 以外は三紀層地すべりに似た oxford clay や Kimmeridge clay の地すべりが目につくが，特に印象深いものは ないので先にあげたオーストリアの三つの地すべりとス カンジナビアの Quick clay の地すべりについて知見し たことを報告する。

\section{2. オーストリアの地すべり}

図-1にオーストリアの地質の概略 ${ }^{20)}$ と以下に述べる地 すべりの位置を示す。オーストリアの地すべり及び土砂

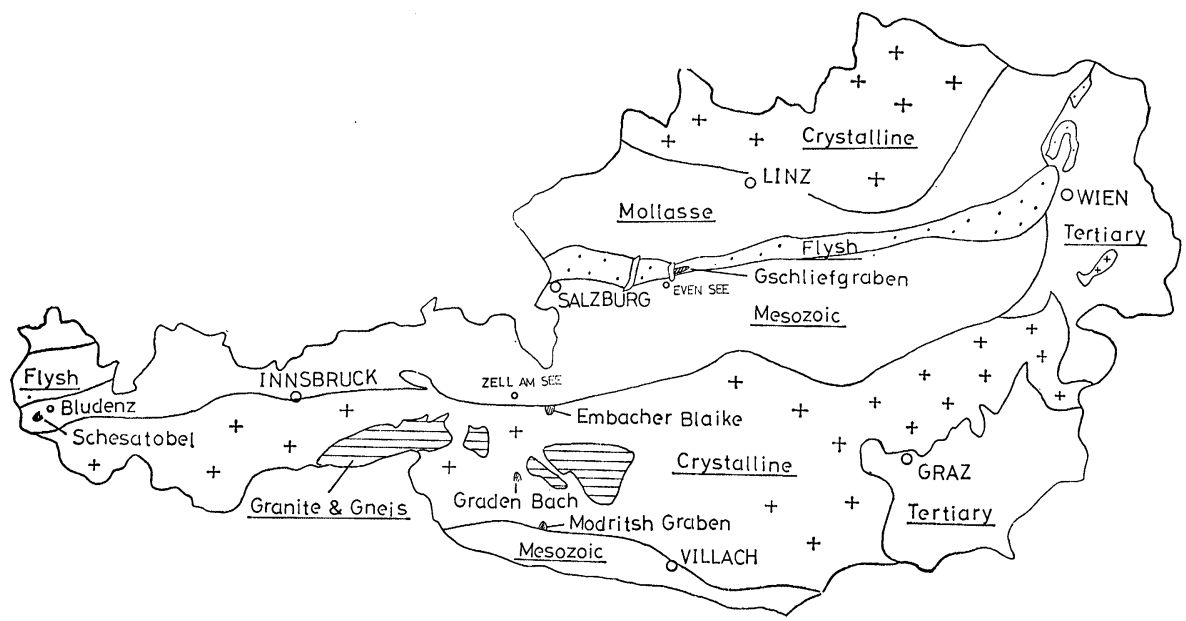

図-1 オーストリアの地質の概略と地すべりの位貴

Fig. 1 Outline of the Austrian geology and the locations of landslides 
地すべり Vol. 15, No. 4 (1979)

災害は 1) モレーン (Moraine) 氷河堆積物の地域, 2) フィリッテ (Phyllite), シーファー (Schiefer) と呼ば れる結晶片岩, 片岩の地域, 3) マール (Marl, Mergel) と呼ばれる泥灰岩の地域, 4)フリッシュ (Flysch) と呼 ばれる砂岩・泥岩の互層の地域, の 4 つに分けられる。 これらのららオーストリアで地すべり, 土石流, 土砂流 出などの大規模な土砂害を引き起しているのはモレーン と結晶片岩の地域である。フリッシュはチェコ等ではか なり問題になっているが, オーストリアでは分布面積が あまり広くないためか，それほど問題ではないようであ った。またマールはモレーン，結晶片岩にくらべると問 題は少ないが, 日本にはないものであり, その地すべり は興味深い。したがって次にオーストリアの地すべりと して, モレーンの地すべり, 結晶片岩の地すべり, マー ルの地すべりの三つをあげ，その各々のタイプの地すべ りの例を報告する。

\section{2-1 モレーン (Moraine) の地すべり}

モレーンはオーストリア全域に広く分布しているが, 堆積年代が新しく固結度が低いことから，各地で表面浸 食, 土石流, 地すべりを引き起している。次に示す地す ベりは Zell am see の近くの国道311号線に面した Embacher Blaike (図-1) と呼ばれる地すべりである。 この地すべりは結晶片岩 (Kristalline Schiefer) の上に モレーンが堆積し，主としてそのモレーンがすべってい ると言われている。しかし上端滑落崖には結晶片岩の層 が露出していることから, すべり面は片岩の層にも入っ ていると思われる。規模は長さ 600m，幅 $400 \mathrm{~m}$ ，深さ は不明だが，上端滑落崖の高さは $60 \mathrm{~m}$ である。記録に 残っている最初の大きな動さは1592年であり，その後， 約100年ごとに大きな動きをくり返し，1698年，1794年， 1935年に大きく動き，末端の Taxen Bach 川に土砂を 押し出し, 川をせき止めた。最大のものは1794年のもの であり, 幅100 150m, 高さ $35 \mathrm{~m}$ の自然ダムがでさた。 約 100 年ごとに動くということは地下浸食, 深層風化に よる土層強度の低下スピー ドの一つの目安と思われ， 地すべりの周期を考觉る上 で興味ある事実である。図 -2はこの地すべりの平面図 である。写真-1は対岸より $200 \mathrm{~mm}$ の望遠で地すべり 上部を写したものである。 地すべり上端の平地はモレ ーンの堆積面であり,この 平地を流れる小川 Salater Bach から地すべりへ地下 水が供給されているとのこ とであった。地すべり全体
の崩壊土量は最初の地形からすると $300 \sim 400$ 万 $\mathrm{m}^{3}$ だろ らと考党られている。

次にプルーデンッ (Bludenz) の近くにあるシェサトー ベ (Schesatobel) をあげる（図-1）。ここは表面浸食, 渓岸浸食, 斜面崩壊, 地すべり, 土石流と砂防に関する ことが何んでも起っている町で, 土砂移動量の点でョー ロッパ最大と言われている。この谷は 180 年前まではご く小さな野渓だったが，1796年に大規模な伐採が行われ たため, 流出率が増大し, 渓床での浸食, 渓岸崩壊が活 発化し，急激に谷が拉大し，1899年に砂防工事が始まる

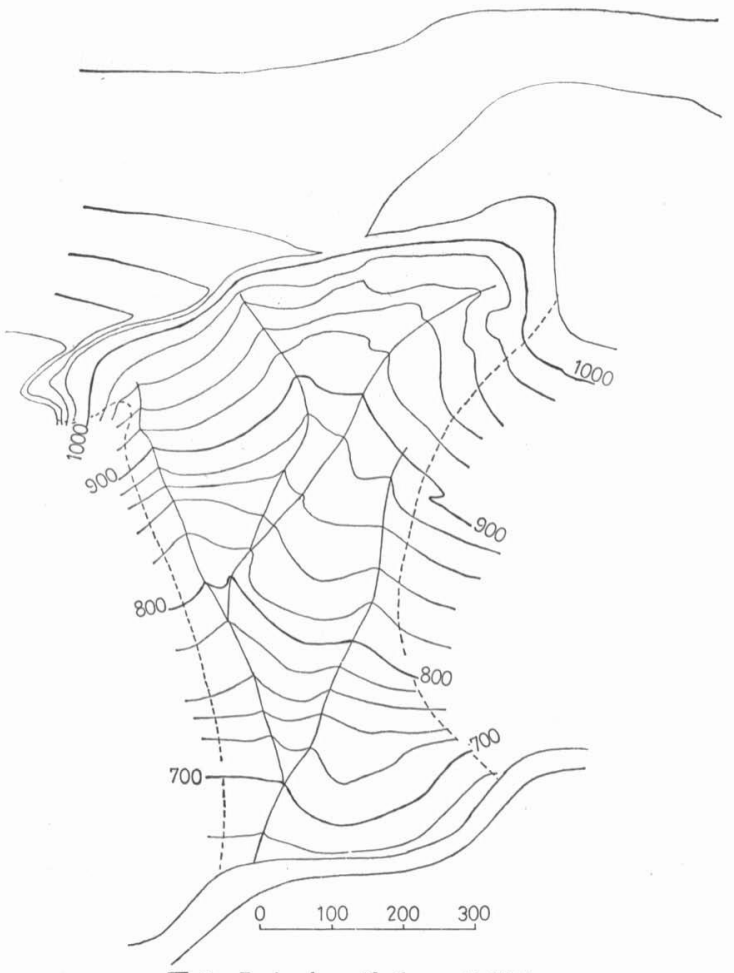

図-2 Embacher Blaike の地形戍

Fig. 2 The map of Embacher Blaike

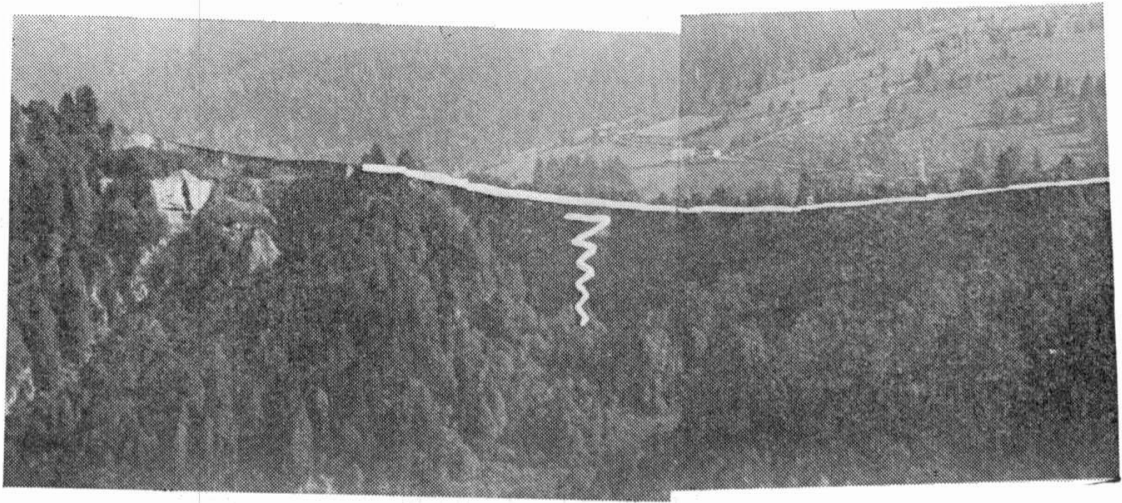

写真-1 Embacher Blaike の上端滑落崖 (200mm 望遠. 対岸より)

Ph. 1 The scarp of Embacher Blaike (200mm telephoto-lens, from the opposite bank) 

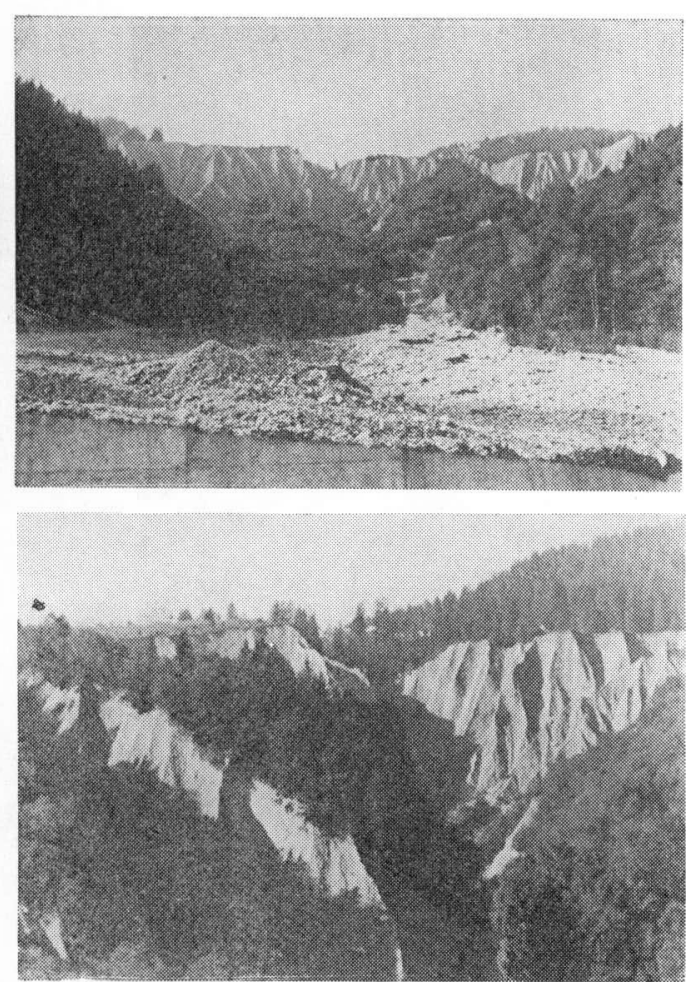

写真-2 Schesatobel の源頭部の全景及び近接写真

Ph. 2 A general view and a close view of top of the Schesatobel

時には長さ $1800 \mathrm{~m}$, 最大幅 $700 \mathrm{~m}$, 谷の深さは最大 200 $\mathrm{m}$, 面積 $60 \mathrm{ha}$ の荒廃地が形成され, 移動した土砂量は 4000 万 $\mathrm{m}^{3}$ に達した。その後, 砂防ダムの設置之側方か らの地すべりにより渓床は平均 $40 \mathrm{~m}$, 最大 $70 \mathrm{~m}$ 上昇し た。写真-2は Schesatobel の源頭部を写したものであ る。写真-3が1965年に側壁で起った 80 万 $\mathrm{m}^{3}$ の地すべり であり, 渓床にあった一連の砂防ダムが埋没した。この 地すべりは砂レキ層の大崩填で, 原因としては溪岸の横 浸食が考光られるが，他に Schesatobel のモレーンの下 にあると言われる Lake deposite の影響があるかもしれ ない。Schesatobel では Lakedeposite の露頭を見ること ができなかったが, Even See の近くの Offen See Bach では白色粘土の Lake deposite の上ですべるモレーンの 地すべりをいくつか見ることができた。

\section{2-2 結晶片岩の地すべり}

オーストリアには花崗岩・片麻岩よりなる中央アルブ スが隆起した際に広域変成作用を受けてできた結晶片 岩, 準片麻岩, 正片麻岩の地域が広く分布している（図 -1 Crystalline の所)。オーストリアの視察では土石流 . 土砂流出のあった Niedersiller, 上流で 1965年 7 ha の 地すべりが起り，著しく河床が荒廃した Silver Tal 他い くつかの結晶片岩地帯の土砂災害地を訪れたが，もっと る感銘を受けたのは Villach の砂防の所長ストリッル博

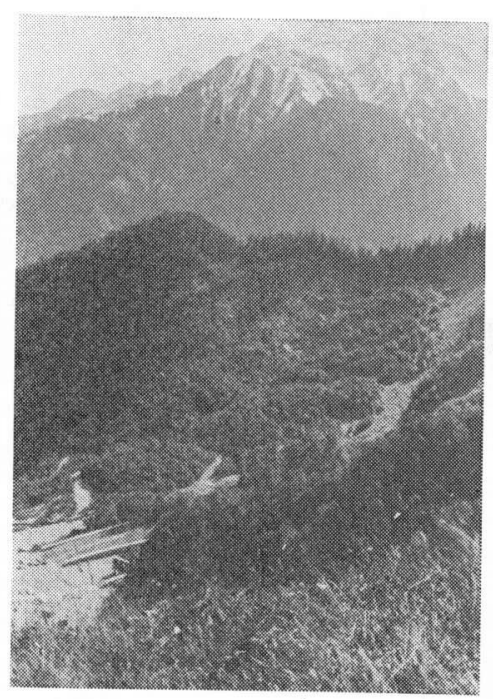

写真-3 Schesatobel 側壁の地すべり

Ph. 3 A landslide in a side slope of Schesatobel

士に案内していただいた Mödritsch Graben と Graden Bach の地すべりである。Mödritsch Graben は氷河時代 の後に, 氷河の消失による徐荷によって動き出したと言 われ, 動きは年平均 $2 \mathrm{~cm}$ 程度と推 定されているが, 1882年, 1966年には大きく動き, 多量の土砂が流出し災 害をひき起した。日本の結晶片岩の地すべりと同じく， ぞこがどう動いているか明確でないとのことであった。 動きは少ないが, すべりは深く, 推力が大きいのでコン トロールは困難と述べていた。次に Graden Bach を視 察した。この地すべりは恐らくオーストリアでもっとも 調査されている地すべりの一つと思われる。これは全長 (水平距離) $1400 \mathrm{~m}$, 高低差 $1000 \mathrm{~m}$, 平均斜度 $28^{\circ}$ の地 すべりで，規模・勾配はちょらど筆者等が調査している 結晶片岩型地すべり・善德地すべりと同じである。すべ り深さはまだ確定して掂らず,視察に来る研究者は100〜 $200 \mathrm{~m}$ と言っているとのことで(筆者には大きすぎるよう に思われた), 現在ボーリング調查が行われている。工事 は渓床の床固めと表面排水以外はなされていないが, 移 動量の測量による測定, 水文調查 (雨量, 涌水量), 地 質調査等がなされている。写真-4は地すべりの全景を国 道から写したもので地すべりの上端滑落崖（かなり硬い 岩の中にすべり面がある) と末端崩壊がみられる。写真 ー5は地すべり上端と末端である。写真-6は床固めが地す べりによる压縮と隆起で破壞されている状況である（数 十基の床固めが添とんど破壊されて扣り, 無事なものは その袖の取り付け部の岩が破壊している)。写真-7は地 すべり末端とみられる泥質片岩 (Phyllite) である。地 層はこの他, 石灰岩質片岩 (Kalkphyllite) や一部珪質 片岩 (Quarzphyllite) がある ${ }^{15)}$ 。図-3は地すべり横断移 動形状を測定するために, 上, 中, 下 3 測線を設置し, 


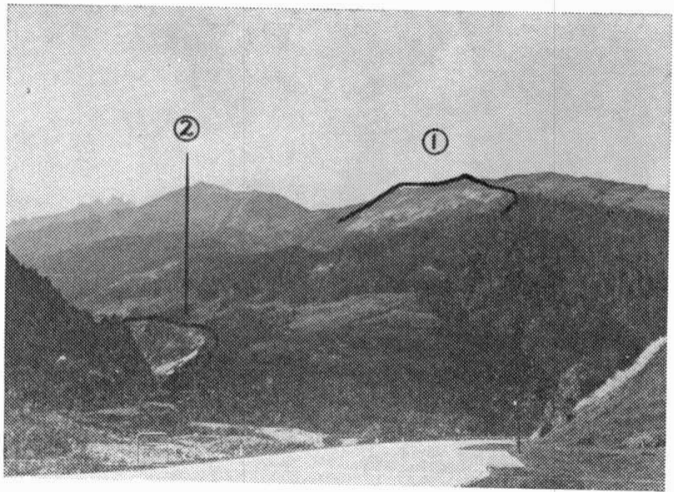

写真-4 Graden Bach 地すべり全景

(1) 上端滑落崖, (2) 末端崩壊

Ph. 4 A general view of the Graden Bach landslide. (1) Main scarp (2) Toe slip
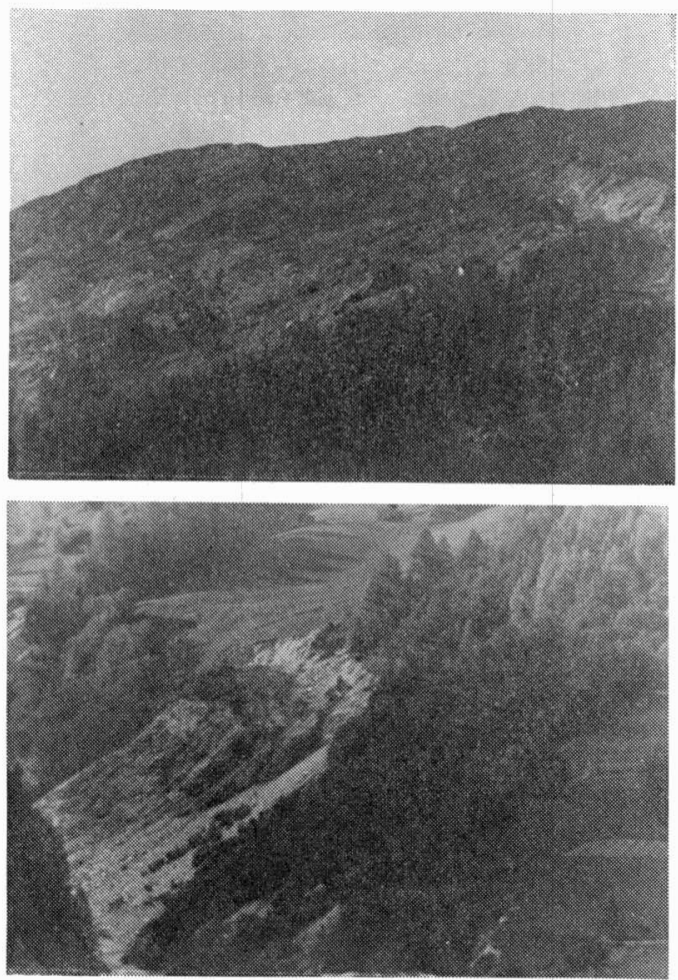

写真-5 Graden Bach 地すぺりの上端滑落崖と末端崩壊の 近接写真 (200mm 望遠レンズ)

Ph. 5 The close views of the scarp and the toe slip in the Graden Bach landslide

各測線に10点程度の測量杭を設置し， 3 角測量により移

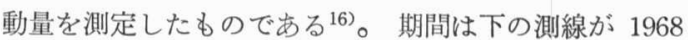
～1975年, 上・中の測線が1969 1975年である。図には 一年毎の移動形状が示されている。地すべり末端で大き い時は年 $2.5 \mathrm{~m}$ ，小さい時で $10 \mathrm{~cm}$ ほど動いている。結 晶片岩型地すべりでは地すべりの境界や地すべりの移動 形態, 移動状沉が踏査ではわかりにくいため, 筆者らは 徳島県善德地すべり地に执いてセン断変位計を製作し,
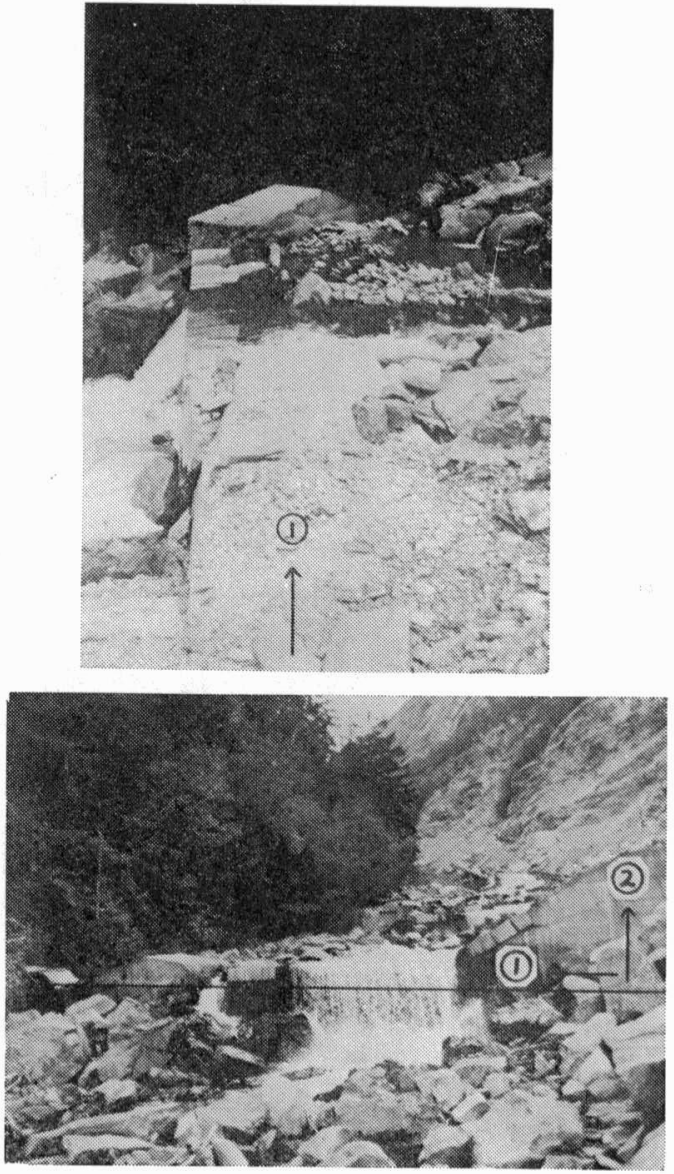

写真-6 Graden Bach 地すべりによる林固工の破壞 (1) 圧縮 (2) 隆起

Ph. 6 Failures of check dams by the Graden Bach landslide. (1) Compression (2) Vpheaval

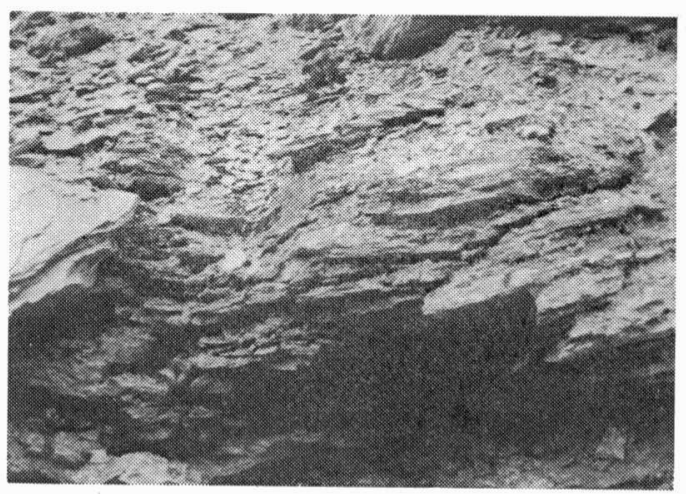

写真-7 Graden Bach 地すべり末端に見られる Phyllite

Ph. 7 Phyllite outcropped in the toe of the Graden Bach landslide

地すべり 横断水平動・上下動の 計器 観測を 続けている が1)2)，オーストリアに拈いても同様な地すべり横断移 動形状の測定が行われているのに興味深かった。また移 動量自体も，善德の場合も年数 $10 \mathrm{~cm}^{5)}$, 大きい時は数 


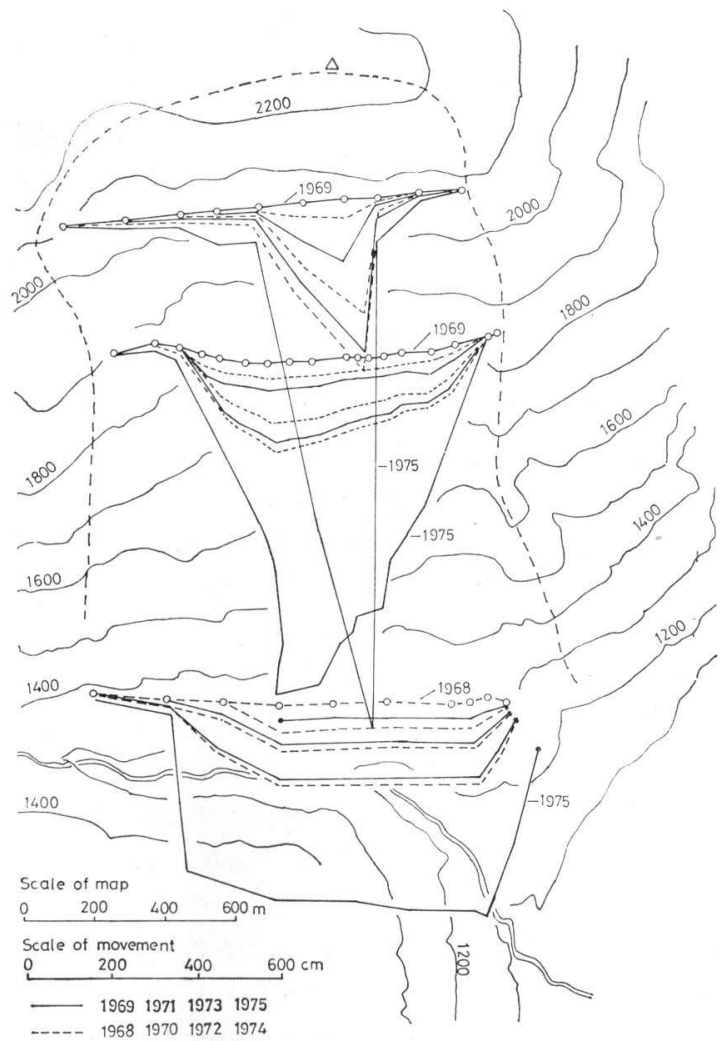

図-3 Gradenbach の地すべりとその移動形状 (Kronfellner Kraus による)

Fig. 3 The Gradenbach Landslide and its movement(after Kronfellner-Kraus)

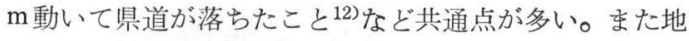
すべり移動の計器測定, 防止工事法などの点で日本に拉 ける研究・経験がオーストリアに执いてかなり役立て得 るものと思われた。話しが少しそれ るが，私が見て回った英国，ノール ウェー，スューデン,オーストリア， チェコ, ユーゴなどと比較すると, 地球物理学的な日本の地すべり移動 測定はもっともレベルが高いように 思われた。

\section{2-3 マールの地すべり}

マールは地学事典 ${ }^{11}$ によれば粘土 質成分と炭酸塩成分との混合した堆 積物であるが, これが風化し, 水を含 むときわめて軟弱になり, 泥流状に なる。チェコに执いて，このマール の上に砂岩がのったまま動くのがみ られたが2177, 次にあげる Gschliefgraben ๖マールの地すべりの一例 である。Gschiefgraben は図- 1 では Flysch のゾーンにあるが，この部分
は飛び石的にマールが出ている所である。ぞの上端部の 模式図が図-4 $4^{19)}$ で下にマールがあり上に角碟岩がのって いる。そしてマールと共に角碩岩の塊も流動している。

案内していただいた Aulitzky 教授はこのような岩の ことを Swimming Rock と呼んでいた。Gschliefgraben は全長 $3.0 \mathrm{~km}$ 注どの谷であるが，その上半分では水が 表面に出ず，地すべりの形で年数的ずつ土層が流下し， 下半分では勾配の減少により mass movement が止まり, 通常の渓流になり, 時折土石流を発生させる。写真-8は 地すべりの流動状況, 写真-9は一時的に地すべりが停止 している所, 写真10は谷の下流で地すべりが停止し, 水 が表面に出て通常の渓流に変わった所である。水が出て くるのが 5 度前後, 地すべりとして動いているのが 10 度 前後である。日本の三紀層地すべりの末期に似ているが， 上に角硚岩をのせている点と上は地すべり, 下は渓流に なっている点がおしらい。

\section{3. スカンジナビアの地すべり}

\section{3-1 Quick Clay の地すべり}

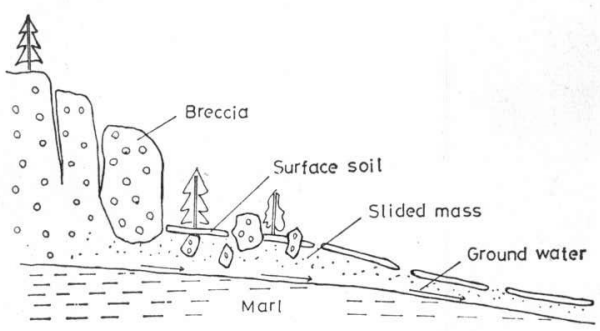

図-4 Gschliefgraben の模式図(Gmunden 砂防事務所による)

Fig. 4 Schematic sketch of Gschliefgraben (after Gmunden Torrent Control Office)
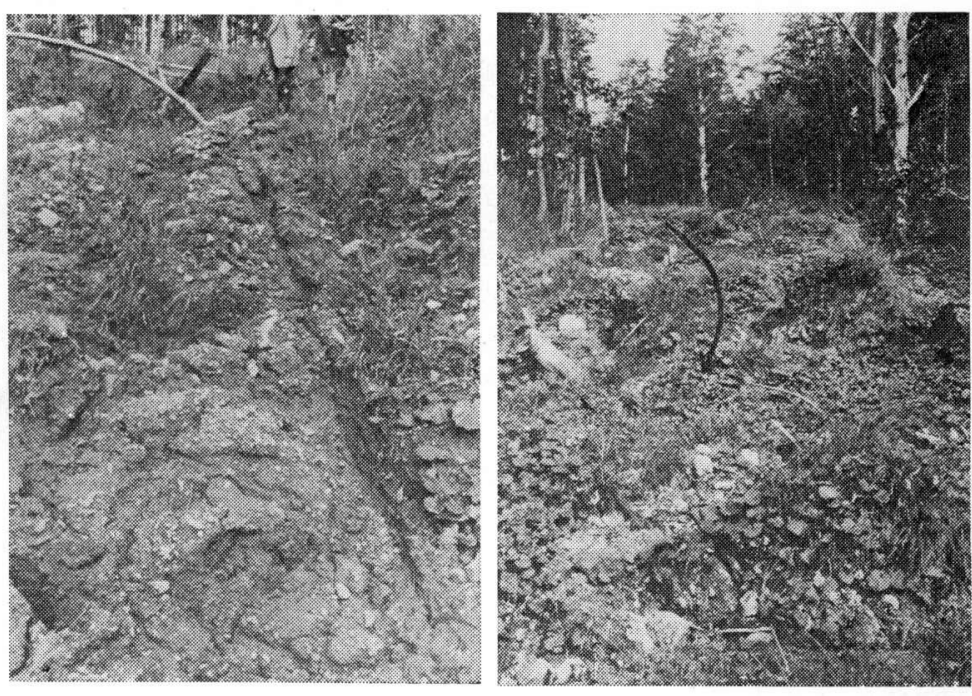

写真-8 Gschliefgraben の流動状沉

Ph. 8 Flow of the Gschliefgraben landslide 
地すべり Vol. 15, No. 4 (1979)

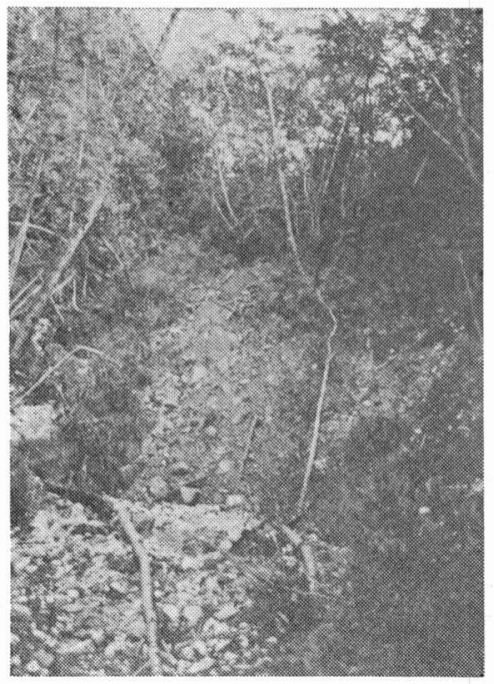

写真-9 地すべりの一時的な停止

Ph. 9 A temporary stop of the landslide

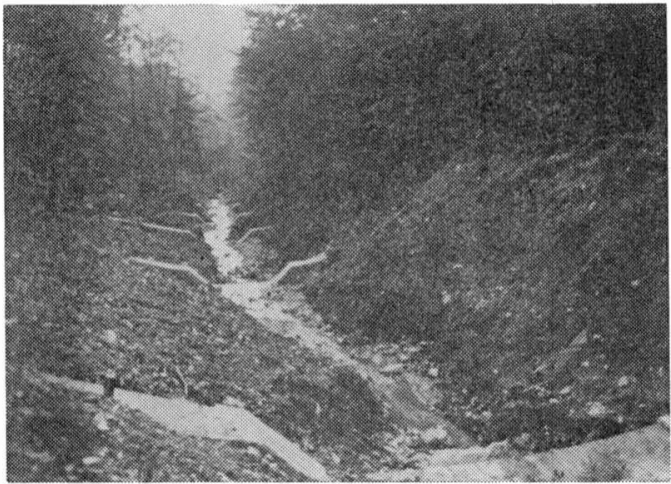

写真-10 Gschliefgraben の下流

Ph. 10 The downstream of Gschliefgraben

スカンジナビアの地すベりと言えば，厚い氷河に過压 密されてできた粘土 Quick Clay の地すべりである。こ の粘土はいったんかく乱されると強度が著し く低下するため，斜面が動き出すと同時に斜 面土 層が 液状化し，泥流状になって 流出す る。日本の三紀層の泥岩の地すべりや英国の 粘土の地すべりでは粘土層はじわじわ動いて もスープのよらになって流動化はしない。日 本では斜面崩壊により流動化するのは, むし ろ水沢新田の地すべりや兵庫県一宮の大崩壊 のような砂質の地すべり, あるいは土石流で ある3)。

ノールウェーのオスロ近郊には沢山の Quick Clay の地すべりの跡があり，お盆の ような形で土がぬけており，その跡にはまた 家が建ったり，畑になったりしている。N. G. I の J $\phi \mathrm{rstad}$ 氏にいろいろ案内していただ
いたが, やはり Quick Clay のすべりの写真としてもっ ともいいのは1953年の Romerike の地すべりの写真と思 われるので，氏の好意により写真-11にそれを示す。こ の地すべりは他の多くの Quick Clay の地すべりと同じ く, 川の河岸浸食により, まず河岸で幅 $30 \mathrm{~m}$, 長さ 40 $\mathrm{m}$ 程度の小崩壊が発生し, その後約 16 時間後にそれを含 む幅 $150 \mathrm{~m}$, 長さ $190 \mathrm{~m}$, 平均深さ $9 \mathrm{~m}$, 土量 10 万 $\mathrm{m}^{3}$ の 地すべりが起り，滑動土塊は液状になって幅 $40 \mathrm{~m}$ の出 ロから川へ流出した ${ }^{17)}$ 。

筆者がロンドンにいた昭和52年11月30日スェーデン第 二の都市 Göteborg 郊外の Tuve 地区で地すべりが起り, 40～50戸の家が破壊されたとのニュースが入った。そこ で昭和53年 5 月に Göteborg を訪れ, Prof. B. Broms 氏 の紹介により, Chalmers Tekniska Högskola の Dr. G. Sällfors 氏にこの地すべりを案内してもらった。この地 すべりについてはスェーデンの新聞報道をもとに藤田が 地すべり学会誌のニュースで報告している10)。

地すべりの地質は基岩が片麻岩でこの岩は地すべりの 両端で上昇し, 地すべり地は埋没谷の形になっている。 基岩の上には $1 \sim 2 \mathrm{~m}$ の砂レキ層があり, その上が鋭敏 比 $5 \sim 600$ の過圧密粘土であり, 地表から $2 \sim 3 \mathrm{~m}$ は clay crust と呼ぱれる乾燥した硬い粘土である。地すべりは 歩く速度〜かけ足ぐらいの速度で約 $150 \mathrm{~m}$ 動き, ほぼ水 平に近い状態で停止した。そこで土層中の間ゲキ水圧が 測定された所, 図-5のよらに流動した過圧密粘土層内で 水圧はほほ全応力に等しく, レキ層では静水圧のレペル に低下していた (Sällfor 氏談)。このことはすべり後数 カ月たってもまだ粘土層が液状になっていることを示し ていると考觉られる。地すべりの原因としては雨とか, 地すべり地内を通っていた下水道からの漏水とかいくつ か考劣られているが，まだ不明である。次に家屋の被災 状況之防止工事を示す。写真-12は家屋の被荻状況で, 中 央の写真は地すべりにより地階, 一階, 二階がばらぱら

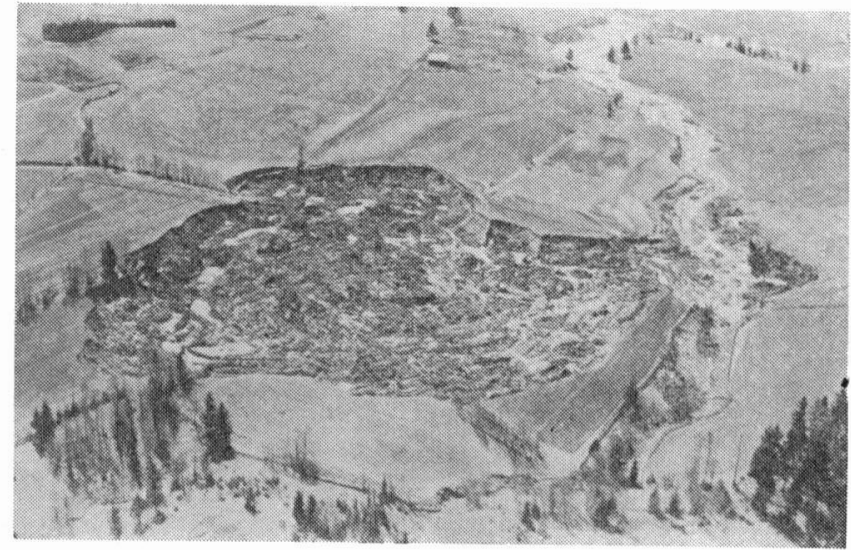

写真-11 Romerike の地すべり (N.G.I. の好意による)

Ph. 11 The Romerike landslide (by courtesy of N.G.I.) 


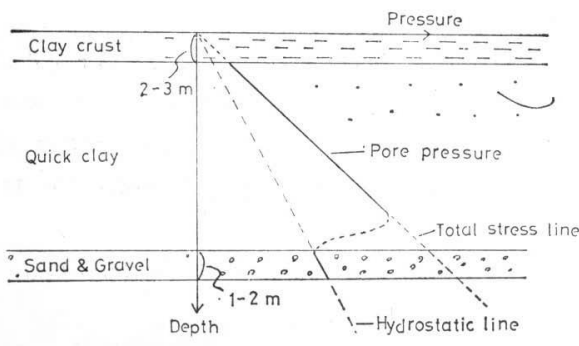

図-5 Göteborg 近 の Tuve 地すべりの間ゲキ水压の分布 (Dr. G. Sällfos 談)

Fig. 5 Schematic figure of the pore pressure in the Tuve landslide near Göteborg (after G. Sällfors)
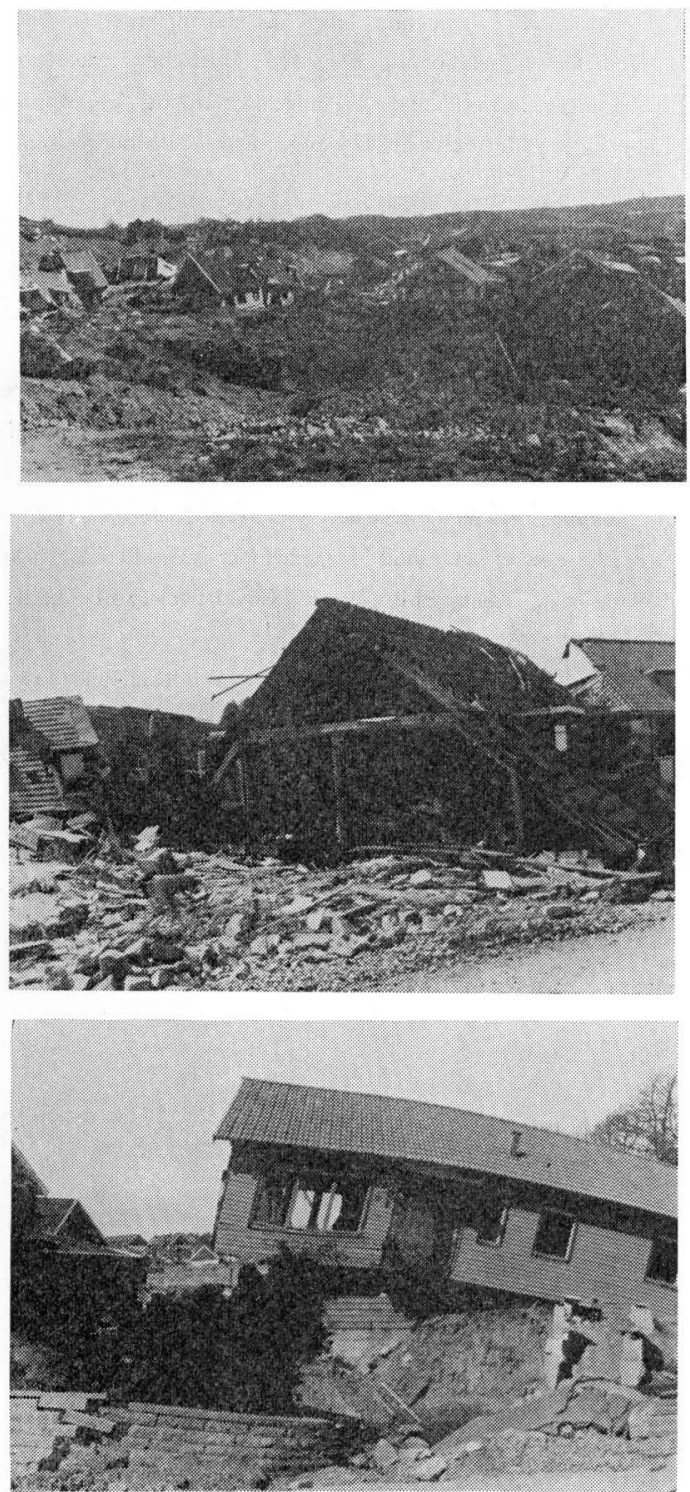

写真-12 Tuve 地すべりの被災状沉

Ph. 12 Destroyed houses by the Tuve landslide

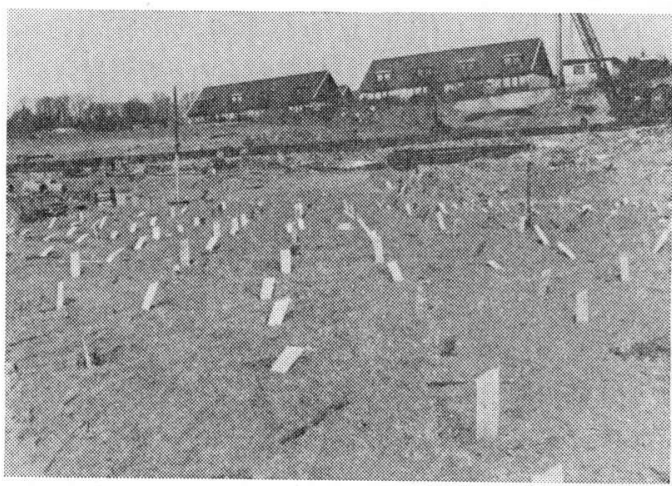

写真-13 Tuve 地すべりに扮ける排水工事

Ph. 13 Drainage of the ground water in the Tuve landslide

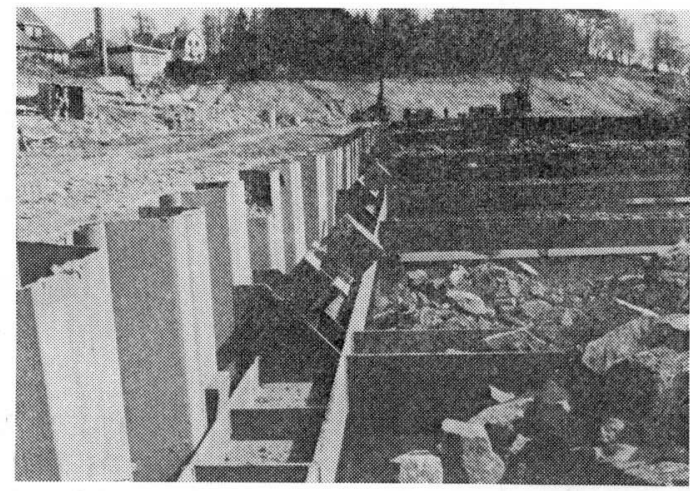

写真-14 Tuve 地すべりにおける地すべり防止埋設ダム工

Ph. 14 A buried dam to prevent houses from The expansion of the landslide

になった家の二階の部分である。写真-13は排水工事で ボーリングしてその中に紙をまいた波状のプラスティッ クを入れたもので, 毛管張力によって地下水の排除を行 らものである。写真-14は地すべりの挔大を防ぐために 人家と地すべりの間に幅 $15 \mathrm{~m}$ の溝をすべり面（7〜 $8 \mathrm{~m})$ まで掘削し, 両側にシートパイルを打込み, 中に 栗石をつめたもので埋設ロックフィルダムみたいなもの である。斜面上端に近いこともあり，地すべり拡大防止 には十分と思われた。

\section{4. おわりに}

以上の報告を支めるにあたって打世話になった方々 とその内容を次に示し，ここに感謝の意を表します。 オーストリア

Prof. H. Aulitzky（ウィーン農科大学教授）：オース トリアに拈ける視察計画の立案, Gschliefgraben の案内, Schesatobel, 及び Embacher Blaike の 資料提供

Chief. Hattinger（オーストリア砂防部長）：視察計画 立案, 手配, コースの説明 
Dr. J. Stritzl (Villach 砂防事務所所長) : Graden Bach, Mödritsch Graben の案内, 資料提供

Dr. A. Fischer (Bludenz 砂防事務所所長) : Schesatobel の案内, 資料提供

Mr. Lerperger（砂防技師）：Embacher Blaike の案内

Mr. F. Kretshmer（砂防技師）: Gschliefgraben の案 内

Dr. C. Dietrich (Vorarlberg 広報局) : Vorarlberg 内 での独一英通訳

スカンジナビア

Prof. B. Broms (The Royal Institute of Technology) : スエーデン内の視察の手配

Dr. G. Sällförs (Chalmers Tekniska Högskola 助教 授)：Göteborg の地すべり案内

Mr. F. J $\phi$ rstad (N. G. I の地質研究者) : Romerike 地すべりの案内（整地されていたが），資料提供 上にあげた方々には上にあげた所以外も案内していた だ、また上にあげた方々以外の方にもオーストリア， スカンジナビアの他の地すべりを案内していただき，い ずれも大変参考になりました。ここに深く感謝の意を表 します。

\section{参考文献}

1）佐々，仲野・武居：破砕带地すべりに打ける地すべり横断 移動形状（水平動，上下動）の測定結果について 一試作し たセン断変位計64台の設置結果よりー, 京都大学演習林報告 No. 47,1975

2）佐々, 武居, 小橋: 三波川片岩類地帯の地すべり移動形態 の特徵 一善徳地すべりにおける現地観測の結果より一, 第 12回自然烦害科学総合シンポジューム, 1975

3）佐々・武居 : 鉛直方向側面破壊の検討一II 一その央例一, 地すべり Vol. 14 No. 3, 1977

4）酒井：英国に批ける代表的な地すべり (Folkestone warren landslide)について, 地すべりVol. 12 No.4, 1976

5）武居・佐々他：德島悲善徳地すべり地調查報告 $I \sim V$, 防 災研究協会, 1973 1978

6）寺川：学会後の巡検紀行，地すべりVol.14, No.4, 1978
7）湊元 : Pre-symposium tour について, 地すべり, Vol. 14, No. 4, 1978

8）中村（浩之）:チェコスロバキア，オーストリアに拈ける 地すべり等の 2,3の問題点, 地すべり Vol. 12, No.4, 1976

9）西田：チェコスロバキアに見られる地すべりの地質環境 一特にカルパチア地域について一, 地すべり Vol.14, No. 4. 1978

10）藤由：Tuve 地すべり，地すべり Vol.14, No.4, 1978

11）地学事典：平凡社, 1973

12）善徳地すべりについて：徳島県土木部砂防課，1971

13) Hutchinson J. N. : A reconsideration of the coastal landslides of Folkeston warren, Kent, Géotechnique 19, 1969

14) Hutchinson J. N. : Periglacial Solifluxion; An approximate mechanism for clayey soil, Géotechnique 24, 1974

15) Häusler H.: Gutachten über die ingenieurgeologischen Untersuchungsergebnisse über die kritischen Massenbewegungen im Gradental, Technisches Büro für Angewandte Geologie -Theoretische Geologie und Anthropogeologie, 1975

16) Kronfellner-Kraus: Die Wildbacherosion in allgemeinen und der Talzuschub im besonderen, 100 Jahre Forstliche Bundesversuchsanstalt, 1974（図-3には1973〜1975の移動量 測定結果をつけ加えた）

17) Kenney T. \& Drury P.: Case Record of the Slope Failure that Initiated the Retrogressive Quick-clay Land. slide at Ullensaker, Norway, Géotechnique 23, 1973

18) Skempton A. W. \& Weeks A. G. : The Quaternary history of the Lower Greensand escarpment and Weald Clay near Sevenoaks, Kent, Phil. Trans. Royal Society of London A-283, 1976

19) Exkursionführer "Gschliefgraben"; Wildbach-und Lawinenverbauung Gebietsbauleitung Gmunden, 1976

20) Geologische Übersichtskarte Der Republik Österreich 1/ 500, 000; Verlay Freytag-Berndt und Artaria, 1963

21) Landslides and other mass movements in noth-western and eastern Bohemia; Guide to the pre-symposium excursion, IAEG, Prague, 1977

（原稿受理日 昭和53年 9 月21日） 